\title{
Attributes of Successful Public Spaces through Users Perception
}

\author{
Maimunah Ramlee, Dasimah Omar, \\ Rodzyah Mohd Yunus, Zalina Samadi
}

\author{
Faculty of Architecture, Planning and Surveying, \\ Universiti Teknologi MARA Shah Alam, Malaysia
}

maimunahramlee@gmail.com

\begin{abstract}
The success of the revitalization program of urban public space is viewed through attributes that have been identified. This study aims to investigate the perception of users in public space through the onsite survey. In summary, the motivations, behavioural patterns, impressions on the public space as an attraction and the perceived importance of urban public spaces in the development of the city are important attributes for successful public space. The findings of this study will show main attributes in successful revitalization of urban public space based on users perception and can be used in a meaningful way to the users.
\end{abstract}

Keywords: Public space; successful attributes; users perception; revitalization

eISSN 2398-4279 @ 2018. The Authors. Published for AMER ABRA cE-Bs by e-International Publishing House, Ltd., UK. This is an open access article under the CC BY-NC-ND license (http://creativecommons.org/licenses/by$n c-n d / 4.0 /$ ). Peer-review under responsibility of AMER (Association of Malaysian Environment-Behaviour Researchers), ABRA (Association of Behavioural Researchers on Asians) and $c E-B s$ (Centre for EnvironmentBehaviour Studies), Faculty of Architecture, Planning \& Surveying, Universiti Teknologi MARA, Malaysia.

https://doi.org/10.21834/ajqol.v3i11.118 


\subsection{Introduction}

Public space is one part of the development of a city. Public spaces play an important role in the public life and enhance the quality of life. If the public space plays an important role in a few matters involving the public and urban areas, public space becomes inevitable components in urban areas.

Public spaces are a physical space that unique and attractive space in urban area. Public space also allows all people from different background regardless of their personal, social and cultural differences to use public space. In addition, public space fulfils various societal needs with different functions and features in order to create connection between peoples and rest of the world. According to Kurniawati, (2012), public spaces have at least three basic things those are responsive-accommodate a variety of activities, interests and desires of the users, democratic-usable and accessible to a variety of human physical condition without any discrimination, and meaningful- have a linkage between human, space and the world at large. Hence, undoubtedly that public space is an indispensable component of an urban area. The significances of public space are through the perspective of individual, community and city.

This paper sets out with the aim of exploring and establishing the attributes of successful public space through users perception. Thus, the main attribute will be useful for the revitalization program of urban public space can be used in a meaningful way to the users.

\subsection{Literature Review}

Public space revitalization program has been designed to bring intercultural communities together (Bagwell et.al, 2012). Therefore, urban public spaces should become the symbols of the contemporary city and tools in the revitalization of cities, thereby recreating the lost identity of a given city. These public spaces reflect the social life and interaction of a people (Okolo et.al, 2010). Meanwhile, Ramezani et.al, (2009), stated that the importance of public space in revitalizing the city in that it generates a sense of palace, as well as a sense of community.

Successful public spaces are characterized by the presence of people, in an often selfreinforcing process (Carmona et.al, 2003). In other words, public spaces accessible to all member of society from children to aged, whereby they can see and enjoy the various activities provided in the public spaces. In physical dimension, the criteria of high-quality public space are the clear and easy access and movement system (Nasution et.al, 2012). According to Project for Public Space (2000), physical dimension could be attained by creating linkage which connect each other and by integration of transportation mode and land use. Without such, the objects, people and information cannot make a movement or exchange from one area to another. In addition, there are also facilities such as traffic signs, street light, parking areas and information signage to facilitate users intercommunication. Hence, according to Project for Pubic Space (2000), they provide a valuable key attributes of successful places. These attributes as a parameter identified by the issues stated after many previous case studies and surveys. Therefore in this study, revitalization of urban public spaces is examined by applying the parameters. 


\subsection{Comfort and image}

Public space as placed where the people are spending a time to carry out recreational activities using the existing facilities. According to Project for Pubic Space (2000), comfort and image are emphasized in the public space in which it determines whether the facilities in public spaces is attraction to encourage more visitors to come to the public space. Moreover, safety and comfort are considered as significant components in the public space, and they have an influence on public space's usage and satisfaction (Namin et.al, 2013).

\subsection{Access and linkages}

In a generalized view, public space is space within the city area which is accessible to all people and is a ground for their activities (Jalaladdini et.al, 2013). An ideal public space should be as "open" as possible, including convenient geographical location, availability of transport links, high visibility to the public, clear entrance and the provision of barrier-free access, in order to ensure everyone in society can enjoy the public space without difficulty (Hong Kong Public Space Initiative, HKPCl, 2012). Therefore, access is very important to connect people with public spaces. According to Project for Pubic Space (2000), a successful public space is visible, easy to get to and around as well as have a high turnover in parking and, ideally, convenient public transit.

\subsection{Uses and activity}

Public Space is not only provided to meet the need of the public but should complemented with uses and activity. The use of public spaces should fully utilized by the public, but not just for certain groups of people only. Public space should have a multi-layer activity so that it can attract not only local public but also the tourists alike. Activities that occur in place-friendly social interactions, free public concerts and more are the reasons why people come in the first place and why they return Project for Pubic Space (2000). The activity that occurs in a public space will also make a place lively, unique and has its identity as well as become more famous.

\subsection{Sociability}

Sociability is an attribute that is difficult to measure but unmistakable quality to achieve. Usually, the purpose of providing public space is to encourage people to carry on recreational activities, creating affection and build social interaction in which it will create a positive interaction between societies. A successful public space should facilitate social interactions among people through accommodating voices of people from all walks of life, eliminating obstructions that discourage interactions, providing venues for performances, exhibitions and recreational activities which all encourage sociability, etc. (HKPCl, 2012). When people see friends, meet and greet their neighbours, and feel comfortable interacting with strangers, they tend to feel a stronger sense of place or attachment to their community and to the place that fosters these types of social activities (Project for Pubic Space (2000). Moreover, Rad et.al, (2013), argues that "when people interact with others, they feel a stronger bond with their society and space. This factor can be measured and evaluated by the amount of different social groups' presence, social nets, and life in a day". 


\subsection{Methodology}

In achieving the aims, this paper adopts perception from local residents and users through an on-site survey. This research explores attributes of public spaces based on the users perception. The sampling technique conducted in this study is probability sampling and the simple random method was applied. Determination of the sample size by using the simple random sampling calculation with a confidence level (95\%) and standard error $(5 \%)$.

In order to study the success of revitalization of urban public space, it is recommended to measure the motivations, behavioural patterns, impressions on the public space as an attribute and the perceived importance of urban public spaces in the development of the city though questionnaire survey.

In this study, there are respondents from various age group and randomly chosen in Padang Kota Lama, Georgetown, Pulau Pinang. In the process of conducting survey, there were 400 respondents answering the survey forms. Self-administered questionnaire survey designed for the respondents. Self-administered questionnaire is the survey where the respondents were asked to complete the document themselves. The purpose of this questionnaire was to investigate the respondents' profile, behaviour patterns of users and perceptions of users as well as detailed information on the attraction of users in urban public space. Apart from that, the respondents were asked about their purpose of visit to public space.

There are three parts in questionnaire survey form. The first part is to simplify the description of the demographic and socio-economic attributes. At the second part, the behavioural pattern of respondents will be analysed such as frequency of visit and length of stay in the public space, visiting time and preferences to bring family members to public space. The third part is to analyse the perceptions about the role of urban public space to the respondent's life, the importance of urban public space to the development of Georgetown and satisfaction of facilities and services. The perceptions and satisfaction of public space is measured in a 1-5 point Likert Scale with scale 1 being not important or strongly disagree to 5 very important or strongly agree. A Likert scale is commonly used to measure attitudes, knowledge, perceptions, values, and behavioral changes (Vogt et.al, 1999).Describe the methodology

\subsection{Findings and Discussions}

The result from the survey has shed some light on the attributes of public space towards successful revitalization program. The data obtained from the respondents were analysed by using descriptive statistic in SPSS software to get the test results for descriptive analysis, cross tabulation and chi-square test. Descriptive analysis was used to determine the minimum, maximum and mean value of the data. Using mean value bigger than 3 is considered as a stronger statement and important to the users. Similarly with the value less than three means that the statement is not so important to them. Chi-square was also conducted to investigate whether there is significantly different between different age groups and between males and females. If the significant level $(a \leq 0.05)$, then there is relationship between age group and gender, but if significant level $(a \geq 0.05)$, then there is no significant 
different between the variable.

From the analysis, shows that the gender, education level from secondary school, relatively in the middle age and moderate income are influencing the successful of public space in attracting people from users perception. This study is parallel with Sangar (2007), stated that public spaces are places that are provided by public authorities for the shared by all people regardless of their personal, social and cultural differences.

According to Table 1 below, there was no significant different between behavioural patterns and age group, but female (mean is 3.381) has a slight effect on the frequency of visit to public space.

Table 1: Chi-square test of behavioural pattern $(a \leq 0.05)$

\begin{tabular}{lll}
\hline Behavioural pattern & Gender & Age \\
\hline Frequency of visit & 0.000 & 0.057 \\
Length of stay & 0.600 & 0.011 \\
\hline
\end{tabular}

\subsection{Purpose of visit}

From the analysis, the most important motivation of visit to study area by respondents is to relax (4.2500), walk (4.1400), for fresh air (4.2800) and to have fun (4.1225). This shows that the purposes of visit to relax, walk, for fresh air and to have fun are influencing the uses and activity in creating successful spaces from the users perception. This study is coincide with Efroymson et.al, (2009), "a wide range of activities occurring in many public spaces indicate that a city still has much to offer in terms of spontaneity, energy, creativity and liveability".

Chi-square test was used to investigate the relationship between the purposes of visit and gender and between age group. Female respondents are much more effect on the purpose of to walk (4.300) and play with child (3.5571), while talking with friends (3.9474) are reasons male respondents. There are slight different purposes of visit for outdoor activities (4.3145) and talking to friends (4.2339) for respondents with age group between $16-25$ years old, while for those of age group 45-59 years old are much more on walking (4.4677) and playing with children (3.6452).

\subsection{Perceived importance of public space in daily life}

It is undeniable that the public space is important in daily life for some people. Therefore, data from of perceived importance of public space in daily life were analysed. The results for perceived importance of public space in daily life are shown in Table 4 below. The respondents perceived that the public space is a place to relax (4.3600), opportunity to communicate (4.3075), space for outdoor activities (4.2850) and public space create happiness (4.2300) in their daily life. It indicates that there are important aspects of public space in their daily life that encouraged users to have active and passive activities, and create physical and social life in order to drive the successful attributes of public space through users perception. 
Table 2: Satisfaction level and chi-square test of perceived importance of public space in daily life

\begin{tabular}{|c|c|c|c|c|c|}
\hline & \multicolumn{3}{|c|}{ Descriptive finding } & \multirow{2}{*}{\multicolumn{2}{|c|}{$\begin{array}{l}\text { Chi-square test } \\
\text { Sig. }(a \leq 0.05)\end{array}$}} \\
\hline & \multirow[t]{2}{*}{ Minimum } & \multirow[t]{2}{*}{ Maximum } & \multirow[t]{2}{*}{ Mean } & & \\
\hline & & & & Gender & Age \\
\hline Communicate & 1 & 5 & 4.3075 & 0.224 & 0.187 \\
\hline For outdoor activities & 1 & 5 & 4.2850 & 0.780 & 0.546 \\
\hline $\begin{array}{l}\text { Indispensable in daily } \\
\text { life }\end{array}$ & 1 & 5 & 3.2150 & 0.273 & 0.039 \\
\hline $\begin{array}{l}\text { Tourists give negative } \\
\text { impact }\end{array}$ & 1 & 5 & 2.6225 & 0.451 & 0.201 \\
\hline Get information & 1 & 5 & 3.5500 & 0.380 & 0.002 \\
\hline Place to relax & 2 & 5 & 4.3600 & 0.174 & 0.041 \\
\hline Disturb daily life & 1 & 5 & 2.1975 & 0.530 & 0.001 \\
\hline Create happiness & 1 & 5 & 4.2300 & 0.431 & 0.021 \\
\hline
\end{tabular}

Table 2 above shows the result that there is no significant different between the perceived importance of public space in daily life and age group except for the opportunity to get information. According to chi-square test, the importance of public space in daily life is slightly imperative for age group between 16-25 years old (3.7742), 26-44 years old (3.5924) and 45-59 years old (3.2903) for the statement of opportunity to get information. Meanwhile there is no significant different gender between the perceived importances of public space in daily life.

\subsection{Perceived importance of public space in urban development}

There are aspects in public space that are important in urban development. According to Table 3 below, public space plays an important role in urban development of Georgetown city particularly in the aspects of improving tourism development and lively of the city.

Table 3: Satisfaction level and chi-square test of perceived importance of public space in urban development

\begin{tabular}{|c|c|c|c|c|c|}
\hline & \multicolumn{3}{|c|}{ Descriptive finding } & \multirow{2}{*}{\multicolumn{2}{|c|}{$\begin{array}{l}\text { Chi-square test } \\
\text { Sig. }(a \leq 0.05)\end{array}$}} \\
\hline & \multirow[t]{2}{*}{ Minimum } & \multirow[t]{2}{*}{ Maximum } & \multirow[t]{2}{*}{ Mean } & & \\
\hline & & & & Gender & Age \\
\hline $\begin{array}{l}\text { Improve urban } \\
\text { environment }\end{array}$ & 2 & 5 & 4.1875 & 0.528 & 0.943 \\
\hline Improve vitality & 2 & 5 & 4.2475 & 0.199 & 0.431 \\
\hline $\begin{array}{l}\text { Formed public } \\
\text { space culture }\end{array}$ & 1 & 5 & 4.2675 & 0.838 & 0.554 \\
\hline $\begin{array}{l}\text { Enhance city } \\
\text { image }\end{array}$ & 1 & 5 & 4.3275 & 0.694 & 0.637 \\
\hline $\begin{array}{l}\text { Connection with } \\
\text { development }\end{array}$ & 1 & 5 & 3.9875 & 0.559 & 0.104 \\
\hline $\begin{array}{l}\text { Build more public } \\
\text { space }\end{array}$ & 1 & 5 & 4.2100 & 0.711 & 0.019 \\
\hline $\begin{array}{l}\text { Improved } \\
\text { economic } \\
\text { development }\end{array}$ & 2 & 5 & 4.0850 & 0.386 & 0.629 \\
\hline $\begin{array}{l}\text { Improved tourism } \\
\text { development }\end{array}$ & 2 & 5 & 4.4650 & 0.081 & 0.461 \\
\hline
\end{tabular}




\begin{tabular}{lccccc} 
Improved lively & 1 & 5 & 4.4275 & 0.034 & 0.827 \\
$\begin{array}{l}\text { Waste of land } \\
\text { resource }\end{array}$ & 1 & 5 & 1.6750 & 0.219 & 0.573 \\
Waste of money & 1 & 5 & 1.5950 & 0.510 & 0.643 \\
\hline
\end{tabular}

This study is parallel with Carr et.al, (1992), regard public space as a fundamental feature of cities and represent sites of sociability and face-to-face interaction, and at the same time their quality is commonly perceived to be a measure of the quality of urban life.

\subsection{Satisfaction level on existing facilities and services in public space}

Public facilities are important elements that need to provide in the public space. Most of the respondents were very satisfied with the facilities and services in public space, except the perception on the availability of parking space and safe and comfortable gazebo. This study confirms what Nasution et.al, (2012), state that such facilities are preferred physical elements of public open space which increasing comfort that encourage attraction to public space through users' perception.

\subsection{Conclusion}

As for the conclusion, this study has proved that the public spaces are an interesting and indispensable component of an urban area and must adhere to the specific attributes. Also, public spaces provide important opportunities for Georgetown residents as a medium in creating a community in the urban area in spontaneous way. Majority of respondents perceived that public spaces as a place to relax and create interaction through communication in their daily life. The public space and people also contribute to the urban development in the perspective of tourism development and lively of the city.

The public spaces perceived as an important element in enhancing the city image and improve the vitality of the city. It seems that public space has provided good facilities and services to the users to enjoy their life. However the lack of some facilities and limitation in physical quality and management aspects as contributing factor to the decline in the number of visitors at public space and make it difficult to attract visitors. It shows that specific attributes need to be in order to achieve successful revitalization of urban public spaces in Padang Kota Lama, Pulau Pinang. Hence, public spaces should accommodate change and people from all sorts of background should be accessible to public spaces with the right to variety (Kurniawati, 2011). To create more successful urban public space, it is important to revitalize the public space as safe, welcoming and accommodating for all users.

\section{Acknowledgement}

The author is grateful to Prof. Dr. Dasimah Omar, Assoc Prof Dr. Rozyah bt. Mohd Yunus and Dr. Zalina bt. Samadi in supporting and professional guidance throughout the success of this study. 


\section{References}

Bagwell, S., Evans, G., Witting, A., \& Worpole, K. (2012). Public space management. London Metropolitan University.

Carmona, M., Heath, T., Oc, T. \& Tiesdell, S. (2003). Public Places - Urban Spaces: The Dimensions of Urban Design. Oxford: Architectural Press.

Carr, S., Francis, M., Rivlin, L. g., \& Stone, A. M. (1992). Public Space. Cambridge: Cambridge University Press.

Efroymson, D., Ha, T.T.K.T., \& Ha, P.T. (2009). Public spaces: How they humanize cities. Retrieved from http://healthbridge.ca/images/uploads/library/Public_Spaces_How_they_Humanize_Cities.pdf

Hong Kong Public Space Initiative, HKPCl, (2012). The Ideal Public Space. Hong Kong: Hong Kong Public Space Initiative.

Kurniawati, W. (2011). Public Space For Marginal People. Procedia -Social and Behavioral Sciences 36, 476-484.

Namin, E. R., Najafpour, H., \& Lamit, H. (2013). Public Places and Spaces and Social Urban Interaction (A Case Study of Johor Bahru, Malaysia). International Journal of Current Engineering and Technology, 3(2), 281-294.

Okolo, N., \& Okolie, A.O. (2010). Revitalizing urban public spaces in Nigeria through vegetative enclaves. Journal of Environmental Management and Safety. 1(1), 124-130.

Rad, V.B., \& Ngah, I. (2013). The Role of Public Spaces in Promoting Social Interactions. International Journal of Current Engineering and Technology, 3(1), 184-188.

Ramezani, S., Aziz, Z. A. A., \& Idid, S. Z. A. (2009). Public space and conservation of a historic living city: Melaka, Malaysia. Retrieved May 20, 2014 from http://www.epublication.fab.utm.my/252/1/routledgevol42010.pdf

Sangar, V. A. (2007). Human Behaviour in Public Spaces. Retrieved from https://www.be.unsw.edu.au/sites/default/files/upload/pdf/schools_and_engagement/resources/_notes/5A2_1.pdf

Vogt, W. P., \& Johnson, R.B. (1999). Dictionary of statistics and methodology. Sage: Thousand Oaks, California. 